\title{
Association between Maternal HCV and Developing Thyroid Disorders: Achievements and Challenges
}

\author{
Ahmed R.G. \\ Division of Anatomy and Embryology, Zoology Department, Faculty of Science, Beni-SuefUniversity, Beni-Suef, \\ Egypt
}

*Corresponding Author: Ahmed R.G., Division of Anatomy and Embryology, Zoology Department, Faculty of Science, Beni-Suef University, Beni-Suef, Egypt

\section{BRIEF COMMUNICATION}

Hepatitis $\mathrm{C}$ virus (HCV; a plus-stranded RNA virus) is recognized to the family Flaviviridae, infected $>200$ million people worldwide (Waheed et al., 2009), and caused death in greater than 350,000 during 2012 (World Health Organization, 2012). 20\% of acute viral hepatitis and 50\% of chronic viral hepatitis (Alter et al., 1992; Kumar et al., 2005) can increase the risk of liver cirrhosis and hepatocellular carcinoma in about more than 170 million patients (World Health Organization, 1997; Kabbaj et al., 2006; Matsumori et al., 2010). The prevalence of HCV differs from area to area and there are 6 genotypes for HCV on the basis of nucleotides sequence divergence (Safi et al., 2010; Waheed, 2015). In pregnant women, the range of anti-hepatitis C virus (HCV) was from $0.7 \%$ to $4.4 \%$ (Hillemanns et al., 1998; Resti et al., 1998) and the rate of viremia was from $63 \%$ to $69 \%$ (Granovsky et al., 1998; Conte et al., 2000).

On the other hand, Many investigations reported that HCV infection was related to thyroid dysfunction (hypothyroidism and thyroid autoimmunity) (Antonelli et al., 2004; Muratori et al., 2005; Tran and Reeves, 2009; de Oliveira Andrade et al., 2011; Fallahi et al., 2014; Shukla et al., 2018). More importantly, other reports recorded that HCV infection can increase the prevalence of thyroid cancer (Antonelli et al., 2007; Giordano et al., 2007; Omland et al., 2010; Wang et al., 2017). These disturbances may be attributed to the following causes: (1) presence of thyroid autoantibodies and autoimmune thyroiditis due to HCV infection (Prummel and Laurberg, 2003; Antonelli et al., 2007); (2) HCV can infect thyroid cells (Bartolome et al., 2008); (3) HCV proteins can initiate apoptosis (Munshi et al., 2003; Balasubramanian et al., 2006); and (4) HCV can activate the pro-inflammatory cytokines (Balasubramanian et al., 2003; Akeno et al., 2008). Then, HCV can stimulate the disorders in the immune system and the development of thyroid cancer (Antonelli et al., 2007; Wang et al., 2017). On account of suitable gestational thyroid hormones (THs) signaling is necessary for the normal development (Ahmed, 2011, 2012a,b, 2013, 2014, 2015a-c, 2016a-d, 2017a-v, 2018a-w; Ahmed and Ahmed, 2012; Ahmed et al., 2013a,b, 2014, 2015a,b, 2018a,b; Van Herck et al., 2013; Ahmed and El-Gareib, 2014; Incerpi et al., 2014; Candelotti et al., 2015; De Vito et al., 2015; ElGhareeb et al., 2016; Ahmed and El-Gareib, 2017), any defects in the levels of 3,5,3'-triiodothyronine (T3) and thyroxine (T4) can cause pre-eclampsia, intrauterine/fetal growth restriction, abortion, preterm delivery, fetal distress, peripartum hemorrhage, and permanent neurodevelopmental dysfunctions (Cunningham et al., 2005; Kumar et al., 2009).

At the end of this commentary, it has been suggested that maternal HCV (chronic hepatitis C) may increase the risk of preterm delivery, teratogenic consequences, child death, and neonatal thyroid disorders (thyroiditis or cancer). The presence of positive thyroid antibodies and macrophages is the prognostic factors of the thyroid disorders. In addition, these disorders may cause several brain disabilities and inflammatory-immune diseases in fetuses, neonates, and childhood. In general, these disturbances may delay the development and growth depending on the severity of HCV and time of its infection. However, the disruption mechanisms of $\mathrm{HCV}$ during the different periods of development are still uncertain. Thus, following the state of the pregnancy and the levels of maternal T3, T4, thyroid-stimulating hormone (TSH), thyroid antibodies, and serum fibrosis markers in the 
presence of $\mathrm{HCV}$ infection should be more significant to avoid or decrease the risk of teratogenic consequences and neonatal thyroid dysfunction. Hopefully, several pharmacogenomics methods will be used to recognize the activity of maternal thyroid gland during the gestation previous to the initiation of HCV treatments. Additional work is vital to determine the developmental (the metabolic pathways), molecular and biochemical disruption mechanisms of maternal HCV infection and its treatment during the fetal and neonatal development. Clinical examinations are still essential to understand the associations between the chronic HCV infection and the prevalence of maternofetal autoimmune thyroid disorders and thyroid cancer. As well, several studies are required to discover novel drugs for HCV treatment and new therapeutic approaches to improve the maternofetal and neonatal health consequences, and to decrease the morbidity and mortality in fetuses, neonates or child.

\section{REFERENCES}

[1] Ahmed, O.M., Abd El-Tawab, S.M., Ahmed, R.G., 2010. Effects of experimentally induced maternal hypothyroidism and hyperthyroidism on the development of rat offspring: I- The development of the thyroid hormones-neurotransmitters and adenosinergic system interactions. Int. J. Dev. Neurosci. 28, 437454.

[2] Ahmed, O.M., Ahmed, R.G., 2012. Hypothyroidism. In A New Look At Hypothyroidism. Dr. D. Springer (Ed.), ISBN: 978-953-51-0020-1), In Tech Open Access Publisher, Chapter 1, pp. 1-20.

[3] Ahmed, O.M., Ahmed, R.G., El-Gareib, A.W., El-Bakry, A.M., Abd El-Tawab, S.M., 2012. Effects of experimentally induced maternal hypothyroidism and hyperthyroidism on the development of rat offspring: II-The developmental pattern of neurons in relation to oxidative stress and antioxidant defense system. Int. J. Dev. Neurosci. 30, 517-537.

[4] Ahmed, O.M., El-Gareib, A.W., El-bakry, A.M., Abd El-Tawab, S.M., Ahmed, R.G., 2008. Thyroid hormones states and brain development interactions. Int. J. Dev. Neu rosci. 26(2), 147-209. Review.

[5] Ahmed, R.G., 2011. Perinatal 2, 3, 7, 8-tetrachlorodibenzo-p-dioxin exposure alters developmental neuroendocrine system. Food Chem. Toxicology, 49, 1276-1284.

[6] Ahmed, R.G., 2012a. Maternal-newborn thyroid dysfunction. In the Developmental Neuroendocrinology, pp. 1-369. Ed R.G. Ahmed. Germany: LAP LAMBERT Academic Publishing GmbH \& Co KG.

[7] Ahmed, R.G., 2012b. Maternal-fetal thyroid interactions, Thyroid Hormone, Dr. N.K. Agrawal (Ed.), ISBN: 978-953-51-0678-4, In Tech Open Access Publisher, Chapter 5, pp. 125-156.

[8] Ahmed, R.G., 2013. Early weaning PCB 95 exposure alters the neonatal endocrine system: thyroid adipokine dysfunction. J. Endocrinol. 219 (3), 205-215.

[9] Ahmed, R.G., 2014. Editorial: Do PCBs modify the thyroid-adipokine axis during development? Annals Thyroid Res. 1(1), 11-12.

[10] Ahmed, R.G., 2015a. Chapter 1: Hypothyroidism and brain development. In advances in hypothyroidism treatment. Avid Science Borsigstr. 9, 10115 Berlin, Berlin, Germany. Avid Science Publications level 6, Melange Towers, Wing a, Hitec City, Hyderabad, Telangana, India. pp. 1-40.

[11] Ahmed, R.G., 2015b. Hypothyroidism and brain developmental players. Thyroid Research J. 8(2), 1-12.

[12] Ahmed, R.G., 2015c. Editorials and Commentary: Maternofetal thyroid action and brain development. J. of Advances in Biology; 7(1), 1207-1213.

[13] Ahmed, R.G., 2016a. Gestational dexamethasone alters fetal neuroendocrine axis. Toxicology Letters, 258, 46-54.

[14] Ahmed, R.G., 2016b. Neonatal polychlorinated biphenyls -induced endocrine dysfunction. Ann. Thyroid. Res. 2 (1), 34-35.

[15] Ahmed, R.G., 2016c. Maternal iodine deficiency and brain disorders. Endocrinol. Metab. Syndr. 5, 223. http://dx.doi.org/10.4172/2161-1017.1000223.

[16] Ahmed, R.G., 2016d. Maternal bisphenol A alters fetal endocrine system: Thyroid adipokine dysfunction. Food Chem. Toxicology, 95, 168-174.

[17] Ahmed, R.G., 2017a. Developmental thyroid diseases and GABAergic dysfunction. EC Neurology 8.1, 02-04.

[18] Ahmed, R.G., 2017b. Hyperthyroidism and developmental dysfunction. Arch Med. 9, 4.

[19] Ahmed, R.G., 2017c. Anti-thyroid drugs may be at higher risk for perinatal thyroid disease. EC Pharmacology and Toxicology 4.4, 140-142.

[20] Ahmed, R.G., 2017d. Perinatal hypothyroidism and cytoskeleton dysfunction. Endocrinol Metab Syndr 6, 271. doi:10.4172/2161-1017.1000271 
[21] Ahmed, R.G., 2017e. Developmental thyroid diseases and monoaminergic dysfunction. Advances in Applied Science Research 8(3), 01-10.

[22] Ahmed, R.G., 2017f. Hypothyroidism and brain development. J. Anim Res Nutr. 2(2), 13.

[23] Ahmed, R.G., 2017g. Antiepileptic drugs and developmental neuroendocrine dysfunction: Every why has A Wherefore? Arch Med 9(6), 2.

[24] Ahmed, R.G., 2017h. Gestational prooxidant-antioxidant imbalance may be at higher risk for postpartum thyroid disease. Endocrinol Metab Syndr 6, 279. doi:10.4172/2161-1017.1000279.

[25] Ahmed, R.G., 2017i. Synergistic actions of thyroid-adipokines axis during development. Endocrinol Metab Syndr 6, 280. doi:10.4172/2161-1017.1000280.

[26] Ahmed, R.G., 2017j. Thyroid-insulin dysfunction during development. International Journal of Research Studies in Zoology 3(4), 73-75. DOI: http://dx.doi.org/10.20431/2454-941X.0304010.

[27] Ahmed, R.G., 2017k. Developmental thyroid diseases and cholinergic imbalance. International Journal of Research Studies in Zoology 3(4), 70-72. DOI: http://dx.doi.org/10.20431/2454-941X.0304009.

[28] Ahmed, R.G., 2017l. Thyroid diseases and developmental adenosinergic imbalance. Int J Clin Endocrinol 1(2), 053-055.

[29] Ahmed, R.G., 2017m. Maternal anticancer drugs and fetal neuroendocrine dysfunction in experimental animals. Endocrinol Metab Syndr 6, 281. doi:10.4172/2161-1017.1000281.

[30] Ahmed, R.G., 2017n. Letter: Gestational dexamethasone may be at higher risk for thyroid disease developing peripartum. Open Journal of Biomedical \& Life Sciences (Ojbili) 3(2), 01-06.

[31] Ahmed, R.G., 2017o. Deiodinases and developmental hypothyroidism. EC Nutrition 11.5, 183-185.

[32] Ahmed, R.G., 2017p. Maternofetal thyroid hormones and risk of diabetes. Int. J. of Res. Studies in Medical and Health Sciences 2(10), 18-21.

[33] Ahmed, R.G., 2017r. Association between hypothyroidism and renal dysfunctions. International Journal of Research Studies in Medical and Health Sciences 2(11), 1-4.

[34] Ahmed, R.G., 2017s. Maternal hypothyroidism and lung dysfunction. International Journal of Research Studies in Medical and Health Sciences 2(11), 8-11.

[35] Ahmed, R.G., 2017t. Endocrine disruptors; possible mechanisms for inducing developmental disorders. International journal of basic science in medicine (IJBSM) 2(4), 157-160.

[36] Ahmed, R.G., 2017u. Maternal thyroid hormones trajectories and neonatal behavioral disorders. ARC Journal of Diabetes and Endocrinology 3(2), 18-21.

[37] Ahmed, R.G., 2017v. Maternal thyroid dysfunction and neonatal cardiac disorders. Insights Biol Med. 1, 092-096.

[38] Ahmed, R.G., 2018a. Maternal hypothyroidism and neonatal testicular dysfunction. International Journal of Research Studies in Medical and Health Sciences 3(1), 8-12.

[39] Ahmed, R.G., 2018b. Maternal hypothyroidism and neonatal depression: Current perspective. International Journal of Research Studies in Zoology 4(1), 6-10. DOI: http://dx.doi.org/10.20431/2454-941X.0401002.

[40] Ahmed, R.G., 2018c. Non-genomic actions of thyroid hormones during development. App Clin Pharmacol Toxicol: ACPT-108. DOI: 10.29011/ACPT-109. 100008.

[41] Ahmed, R.G., 2018d. Maternal thyroid function and placental hemodynamics. ARC Journal of Animal and Veterinary Sciences 4(1), 9-13. DOI: http://dx.doi.org/10.20431/2455-2518.0401002.

[42] Ahmed, R.G., 2018e. Interactions between thyroid and growth factors during development. ARC Journal of Diabetes and Endocrinology 4(1), 1-4. DOI: http://dx.doi.org/10.20431/2455-5983.0401001.

[43] Ahmed, R.G., 2018f. Maternal thyroid hormones and neonatal appetite. ARC Journal of Nutrition and Growth 4(1), 18-22. DOI: http://dx.doi.org/10.20431/2455-2550.0401005.

[44] Ahmed, R.G., 2018g. Genomic actions of thyroid hormones during development. ARC Journal of Diabetes and Endocrinology 4(1), 5-8. DOI: http://dx.doi.org/10.20431/2455-5983.0401002.

[45] Ahmed, R.G., 2018h. Dysfunction of maternal thyroid hormones and psychiatric symptoms. American Research Journal of Endocrinology. 2(1), 1-6.

[46] Ahmed, R.G., 2018i. Is there a connection between maternal hypothyroidism and developing autism spectrum disorders? ARC Journal of Neuroscience 3(1), 5-8. DOI: http://dx.doi.org/10.20431/2456057X.0301002.

[47] Ahmed, R.G., 2018j. Maternal thyroid dysfunctions and neonatal bone maldevelopment. American Research Journal of Endocrinology (in press) xx-xxx.

[48] Ahmed, R.G., 2018k. Maternal thyroid disorders and risk of neonatal seizure: Current perspective. ARC Journal of Neuroscience 3(1), 21-25. DOI: http://dx.doi.org/10.20431/2456-057X.0301004 
[49] Ahmed, R.G., 20181. Gestational dioxin acts as developing neuroendocrine-disruptor. EC Pharmacology and Toxicology 6.3, 96-100.

[50] Ahmed, R.G., 2018m. Maternal thyroid dysfunction and risk of neonatal stroke. ARC Journal of Animal and Veterinary Sciences 4(1), 22-26. DOI: http://dx.doi.org/10.20431/2455-2518.0401004

[51] Ahmed, R.G., 2018n. Maternal thyroid disorders and developing skin dysfunctions. ARC Journal of Dermatology 3(1), 13-17. DOI: http://dx.doi.org/10.20431/2456-0022.0301005

[52] Ahmed, R.G., 2018o. Maternal hypothyroidism-milk ejections: What is the link? ARC Journal of Nutrition and Growth 4(1), 29-33. DOI: http://dx.doi.org/10.20431/2455-2550.0401007

[53] Ahmed, R.G., 2018p. Does maternal antepartum hypothyroidism cause fetal and neonatal hyponatremia? ARC Journal of Diabetes and Endocrinology 4(1), xx-xxx. DOI: http://dx.doi.org/10.20431/24555983.0401004

[54] Ahmed, R.G., 2018q. Maternal hypothyroidism and rheumatoid arthritis. International Journal of Research Studies in Medical and Health Sciences Volume 3(2), 1-5.

[55] Ahmed, R.G., 2018r. Developmental thyroid and skeletal muscle dysfunction. ARC Journal of Diabetes and Endocrinology 4(1), xx-xxx. DOI: http://dx.doi.org/10.20431/2455-5983.0401003.

[56] Ahmed, R.G., 2018s. Hyperthyroidism and renal disorders. ARC Journal of Animal and Veterinary Sciences 4(2), XX-XX. DOI: http://dx.doi.org/10.20431/2455-2518.0402001

[57] Ahmed, R.G., 2018t. Maternal hypothyroidism and developing hyperhomocysteinemia. ARC Journal of Nutrition and Growth 4(2), xx-xxx. DOI: http://dx.doi.org/10.20431/2455-2550.0402002

[58] Ahmed, R.G., 2018u. Maternal hyperthyroidism and neonatal testicular dysfunction. ARC Journal of Urology 3(1), xx-xxx. DOI: http://dx.doi.org/10.20431/2456-060X.0301002

[59] Ahmed, R.G., 2018v. Maternal hypothyroidism-developing dyslipidemia: What is the connection? ARC Journal of Pharmaceutical Sciences (AJPS) 4(1), 1-6. DOI: http://dx.doi.org/10.20431/24551538.0401001

[60] Ahmed, R.G., 2018w. Maternal iodine deficiency and pregnancy complications: Still a health issue for the pregnant and fetuses. ARC Journal of Pharmaceutical Sciences (AJPS) 4(1), 7-11. DOI: http://dx.doi.org/10.20431/2455-1538.0401002

[61] Ahmed, R.G., Abdel-Latif, M., Ahmed F., 2015a. Protective effects of GM-CSF in experimental neonatal hypothyroidism. International Immunopharmacology 29, 538-543.

[62] Ahmed, R.G., Abdel-Latif, M., Mahdi, E., El-Nesr, K., 2015b. Immune stimulation improves endocrine and neural fetal outcomes in a model of maternofetal thyrotoxicosis. Int. Immunopharmacol. 29, 714-721.

[63] Ahmed, R.G., Davis, P.J., Davis, F.B., De Vito, P., Farias, R.N., Luly, P., Pedersen, J.Z., Incerpi, S., 2013a. Nongenomic actions of thyroid hormones: from basic research to clinical applications. An update. Immunology, Endocrine \& Metabolic Agents in Medicinal Chemistry, 13(1), 46-59.

[64] Ahmed, R.G., El-Gareib, A.W. 2014. Lactating PTU exposure: I- Alters thyroid-neural axis in neonatal cerebellum. Eur. J. of Biol. and Medical Sci. Res. 2(1), 1-16.

[65] Ahmed, R.G., El-Gareib, A.W., 2017. Maternal carbamazepine alters fetal neuroendocrine-cytokines axis. Toxicology 382, 59-66.

[66] Ahmed, R.G., El-Gareib, A.W., Incerpi, S., 2014. Lactating PTU exposure: II- Alter's thyroid-axis and prooxidant-antioxidant balance in neonatal cerebellum. Int. Res. J. of Natural Sciences 2(1), 1-20.

[67] Ahmed, R.G., El-Gareib, A.W., Shaker, H.M., 2018a. Gestational 3, 3', 4, 4', 5-pentachlorobiphenyl (PCB 126) exposure disrupts fetoplacental unit: Fetal thyroid-cytokines dysfunction. Life Sciences 192, 213220.

[68] Ahmed, R.G., Incerpi, S., 2013. Gestational doxorubicin alters fetal thyroid-brain axis. Int. J. Devl. Neuroscience 31, 96-104.

[69] Ahmed, R.G., Incerpi, S., Ahmed, F., Gaber, A., 2013b. The developmental and physiological interactions between free radicals and antioxidant: Effect of environmental pollutants. J. of Natural Sci. Res. 3(13), 74110 .

[70] Ahmed, R.G., Walaa G.H., Asmaa F.S., 2018b. Suppressive effects of neonatal bisphenol A on the neuroendocrine system. Toxicology and Industrial Health Journal (in press).

[71] Akeno, N., Blackard, J.T., Tomer, Y., 2008. HCV E2 protein binds directly to thyroid cells and induces IL-8 production: a new mechanism for HCV induced thyroid autoimmunity. J Autoimmun. 31(4), 339-44.

[72] Alter, M.J., Margolis, H.S., Krawczynski, K., Judson, F.N., Mares, A., Alexander, W., 1992. The natural history of community acquired hepatitis $\mathrm{C}$ in the United States: the Sentinel Counties Chronic Non-A Non-B Hepatitis Study Team. Engl J Med 327, 1899-905. 
[73] Antonelli, A., Ferri, C., Fallahi, P., Pampana, A., Ferrari, S.M., Barani, L., 2007. Thyroid cancer in HCVrelated chronic hepatitis patients: a case-control study. Thyroid 17, 447-51.

[74] Antonelli, A., Ferri, C., Pampana, A., Fallahi, P., Nesti, C., Pasquini, M., Marchi, S., Ferrannini, E., 2004. Thyroid disorders in chronic hepatitis C. Am J Med. 117(1), 10-3.

[75] Balasubramanian, A., Ganju, R.K., Groopman, J.E., 2003. Hepatitis C virus and HIV envelope proteins collaboratively mediate interleukin-8 secretion through activation of p38 MAP kinase and SHP2 in hepatocytes. J Biol Chem 278(37), 35755-66.

[76] Balasubramanian, A., Ganju, R.K., Groopman, J.E., 2006. Signal transducer and activator of transcription factor 1 mediates apoptosis induced by hepatitis $\mathrm{C}$ virus and HIV envelope proteins in hepatocytes. J Infect Dis 194(5), 670-81.

[77] Bartolome, J., Rodriguez-Inigo, E., Quadros, P., Vidal, S., Pascual-Miguelanez, I., Rodriguez-Montes, J.A., 2008. Detection of hepatitis $\mathrm{C}$ virus in thyroid tissue from patients with chronic HCV infection. J Med Virol 80(9), 1588-94.

[78] Candelotti, E., De Vito, P., Ahmed, R.G., Luly, P., Davis, P.J., Pedersen, J.Z., Lin, H-Y., Incerpi, I., 2015. Thyroid hormones crosstalk with growth factors: Old facts and new hypotheses. Immun., Endoc. \& Metab. Agents in Med. Chem., 15, 71-85.

[79] Conte, D., Fraquelli, M., Prati, D., Colucci, A., Minola, E., 2000. Prevalence and clinical course of chronic hepatitis c virus (hcv) infection and rate of HCV vertical transmission in a cohort of 15,250 pregnant women. Hepatology 31, 751- 755.

[80] Cunningham, F.G., Leveno, K.J., Bloom, S.L., Hauth, J.C., Gilstrap, L., Wenstrom, K.D., 2005. Editors. Thyroid and other endocrine disorder. In: Williams's obstetrics. 22nd edn. New York: McGraw Hill, pp. 1189-208.

[81] De Oliveira Andrade, L.J., Atta, A.M., de Sousa Atta, M.L.B., Mangabeira, C.N.K., Parana, R., 2011. Thyroid disorders in patients with chronic hepatitis $\mathrm{C}$ using interferon-alpha and ribavirin therapy. Braz $\mathrm{J}$ Infect Dis 15(4), 377-381.

[82] De Vito, P., Candelotti, E., Ahmed, R.G., Luly, P., Davis, P.J., Incerpi, S., Pedersen, J.Z., 2015. Role of thyroid hormones in insulin resistance and diabetes. Immun., Endoc. \& Metab. Agents in Med. Chem., 15, 86-93.

[83] El-bakry, A.M., El-Ghareeb, A.W., Ahmed, R.G., 2010. Comparative study of the effects of experimentally-induced hypothyroidism and hyperthyroidism in some brain regions in albino rats. Int. J. Dev. Neurosci. 28, 371-389.

[84] El-Ghareeb, A.A., El-Bakry, A.M., Ahmed, R.G., Gaber, A., 2016. Effects of zinc supplementation in neonatal hypothyroidism and cerebellar distortion induced by maternal carbimazole. Asian Journal of Applied Sciences 4(04), 1030-1040.

[85] Fallahi, P., Ferrari, S.M., Politti, U., Giuggioli, D., Ferri, C., Antonelli, A., 2014. Autoimmune and neoplastic thyroid diseases as sociated with hepatitis C chronic infection. Int J Endocrinol. 935131.

[86] Giordano, T.P., Henderson, L., Landgren, O., Chiao, E.Y., Kramer, J.R., El-Serag, H., 2007. Risk of nonHodgkin lymphoma and lymphoproliferative precursor diseases in US veterans with hepatitis $\mathrm{C}$ virus. JAMA 297, 2010-7.

[87] Granovsky, M.O., Minkoff, H.L., Tess, B.H., Waters, D., Hatzakis, A., Devoid, D.E., Landesman, S.H., 1998. Hepatitis C virus infection in the mothers and infants cohort study. Pediatrics 1998; 102:355-359.

[88] Hillemanns, P., Langenegger, P., Langer, B.C., Knitza, R., Hasbargen, U., Hepp, H., 1998. Prevalence and follow-up of hepatitis C virus infection in pregnancy. Z Geburtsh Neonatol 202, 127-130.

[89] Incerpi, S., Hsieh, M-T., Lin, H-Y., Cheng, G-Y., De Vito, P., Fiore, A.M., Ahmed, R.G., Salvia, R., Candelotti, E., Leone, S., Luly, P., Pedersen, J.Z., Davis, F.B., Davis, P.J., 2014. Thyroid hormone inhibition in L6 myoblasts of IGF-I-mediated glucose uptake and proliferation: new roles for integrin avß3. Am. J. Physiol. Cell Physiol. 307, C150-C161.

[90] Kabbaj, N., Guedira, M.M., El Atmani, H., El Alaoui, M., Mohammadi, M., Benabed, K., Lachkar, H., Benaïsa, A., 2006. Thyroid disorders during interferon alpha therapy in 625 patients with chronic hepatitis C: A prospective cohort study. Ann. Endocrinol. 67(4), 343-347.

[91] Kumar, A., Agarwal, K., Gupta, R.K., Kar, P., 2009. Obstetric outcome in women with hepatitis C virus infection and thyroid dysfunction. Acta Obstetricia ET Gynecologica. 88, 1133-1137.

[92] Kumar, A., Sharma, K.A., Guptaa, R.K., Kar, P., Murthy, N.S., 2005. Hepatitis C virus infection during pregnancy in North India. International Journal of Gynecology and Obstetrics 88, 55-56.

[93] Matsumori, A., Shimada, M., Obata, T., 2010. Leukocytes are the major target of hepatitis C virus infection: Possible mechanism of multiorgan involvement including the heart. CVD Prevention and Control 5, 51-58. 
[94] Munshi, N., Balasubramanian, A., Koziel, M., Ganju, R.K., Groopman, J.E., 2003. Hepatitis C and human immunodeficiency virus envelope proteins cooperatively induce hepatocytic apoptosis via an innocent bystander mechanism. J Infect Dis 188(8), 1192-204.

[95] Muratori, L., Bogdanos, D.P., Muratori, P., Lenzi, M., Granito, A., Ma, Y., Mieli-Vergani, G., Bianchi, F.B., Vergani, D., 2005. Susceptibility to thyroid disorders in hepatitis C. Clin Gastroenterol Hepatol. 3(6), 595-603.

[96] Omland, L.H., Farkas, D.K., Jepsen, P., Obel, N., Pedersen, L., 2010. Hepatitis C virus infection and risk of cancer: a population-based cohort study. Clin Epidemiol.2, 179-86.

[97] Prummel, M.F., Laurberg, P., 2003. Interferon-alpha and autoimmune thyroid disease. Thyroid 13, 54751.

[98] Resti, M., Azzari, C., Mannelli, F., Moriondo, M., Novembre, E., de Martino, M., Vierucci, A., 1998. Mother to child transmission of hepatitis $\mathrm{C}$ virus: prospective study of risk factors and timing of infection in children born to women seronegative for HIV-1. Tuscany Study Group on Hepatitis C Virus Infection. BMJ 317, 437-441.

[99] Safi, S.Z., Badshah, Y., Waheed, Y., Fatima, K., Tahir, S., Shinwari, A., 2010. Distribution of hepatitis C virus genotypes, hepatic steatosis and their correlation with clinical and virological factors in Pakistan. Asian Biomed 4, 25 3-262.

[100] Shukla, S.K., Singh, G., Ahmad, S., Pant, P., 2018. Infections, genetic and environmental factors in pathogenesis of autoimmune thyroid diseases. Microbial Pathogenesis 116, 279-288.

[101] Tran, H.A., Reeves, G.E., 2009. The spectrum of autoimmune thyroid disease in the short to medium term following interferon alpha therapy for chronic hepatitis C. Int J Endocrinol. 2009, 241786.

[102] Van Herck, S.L.J., Geysens, S., Bald, E., Chwatko, G., Delezie, E., Dianati, E., Ahmed, R.G., Darras, V.M., 2013. Maternal transfer of methimazole and effects on thyroid hormone availability in embryonic tis sues. Endocrinol. 218, 105-115.

[103] Waheed, Y., 2015. Effect of interferon plus ribavirin therapy on hepatitis C virus genotype 3 patients from Pakistan: Treatment response, side effects and future prospective. Asian Pacific Journal of Tropical Medicine 85-89.

[104] Waheed, Y., Shafi, T., Safi, S.Z., Qadri, I., 2009. Hepatitis C virus in Pakistan: A systematic review of prevalence, genotypes and risk factors. World J Gastroenterol 45, 5647-5653.

[105] Wang, P., Jing, Z., Liu, C., Xu, M., Wang, P., Wang, X., Yin, Y., Cui, Y., Ren, D., Rao, X., 2017. Hepatitis $\mathrm{C}$ virus infection and risk of thyroid cancer: A systematic review and meta-analysis. Arab Journal of Gastroenterology 18, 1-5.

[106] World Health Organization, 1997. Hepatitis C: global prevalence. Wkly Epidemiology Rec 72, 341-4.

[107] World Health Organization, 2012. Prevention and control of viral hepatitis infection. Genewa: WHO Press; 2012[Access on 2013 Aug 30]. Available from: http://www.who.int/csr/disease/hepatitis/GHP_framework.pdf.

Citation: Ahmed R.G., "Association between Maternal HCV and Developing Thyroid Disorders: Achievements and Challenges", ARC Journal of Pharmaceutical Sciences (AJPS) , vol. 4, no. 2, p. 12-17, 2018. http://dx.doi.org/10.20431/2455-1538.0402002

Copyright: (C) 2017 Authors. This is an open-access article distributed under the terms of the Creative Commons Attribution License, which permits unrestricted use, distribution, and reproduction in any medium, provided the original author and source are credited 